\title{
God and Natural Disasters
}

\section{Bethany Sollereder}

The television interrupts our daily pattern with breaking news. An earthquake has devastated part of the world. Pictures pour in of people sorting through collapsed houses, looking for their loved ones. Or a tsunami has swept away an entire coastline. Grainy videos of crowds running in vain away from an unrelenting flood play themselves out over and over again. We watch the desperate work of relief organisations to provide basic necessities to thousands of displaced people so that the casualties from the natural disaster do not climb still higher.

We are familiar with the statistics of loss in earthquakes: the 2004 Indonesia Boxing Day earthquake, 9.1 magnitude, claimed 230-240,000 deaths; on 12 January 2010 in Haiti a 7.0 magnitude earthquake caused some 140,000 deaths; 11 March 2011 an undersea megathrust with a 9.0 magnitude covered 217 square miles of Japan with flood waters, taking 15,893 lives and causing a major meltdown of the Fukushima nuclear power plant.

Earthquakes are so big and unpredictable that they have unrivalled casualties amongst natural disasters, but other disasters can also have sizeable local effects. On 13 November 1985, the Nevado del Ruiz volcano in Columbia erupted. Landslides and mudslides caused by the force of the eruption engulfed a nearby town, killing over 20,000 people. In $79 \mathrm{CE}$, Mount Vesuvius erupted and covered the nearby towns of Herculaneum and Pompeii with ash and burning gases. 1500 deaths have been confirmed by uncovering body casts amongst the well-preserved remains. Estimates for how many lives the eruption actually took run over 10,000. 
In light of such tragic natural disasters, by no means uncommon, how can theists believe in a God who is both powerful and good? The problem of suffering in light of a God characterised by the "omni's"-omnipotence, omniscience, and omnibenevolence — remains one of the greatest challenges in theology.

I am regularly asked to design and deliver talks and workshops for students, fellow academics, and for public audiences. I write, speak, and worship as a practicing Christian theologian, and organisers who make the invitations anticipate that I can help frame how someone can believe in a good and loving God whilst being aware that reality includes disasters of this type. Teachers are likely to want to, and are encouraged to, expand the material and ideas offered here to include the perspectives of other faiths. ${ }^{1}$ With that said, I hope the ideas and activities outlined here will be a useful and informative starting point.

In my workshop designed for secondary students, I begin by outlining the problem, as described above. Then we explore various Christian theological responses to the question of natural disasters. We take time examining, critiquing, and analysing the implications of several different approaches. Some positions are well known and widely held, others represent some of the newest thought amongst academic theologians. All the positions are presented as possibilities, and none of them are given as "the Christian answer". ${ }^{2}$ The seven positions I explore, I label as:

1) The sin approach

2) The Satanic influence approach

\footnotetext{
${ }^{1}$ My own expertise is insufficient to comment on how other faith traditions approach suffering.

2 The most innovative and recent works in theodicy (that branch of theology that deals with suffering) do not offer simple solutions, but hold that viable approaches must be compound. Various lines of argument should be held together, and even so, it is not commonly thought that these approaches give a final answer. Christopher Southgate, The Groaning of Creation: God, Evolution, and the Problem of Evil (Louisville, KY: Westminster John Knox Press, 2008), 15-16; Michael Murray, Nature Red in Tooth and Claw: Theism and the Problem of Animal Suffering (Oxford: Oxford University Press, 2008) 193-199.
} 
3) The kenotic approach

4) The development approach (or "nomic regularity")

5) The physical package deal

6) The co-suffering approach

7) Redemptive responses

In each, I try to show how the perspective is either supported or critiqued by the input of modern science. The aim is to show that theology does not have just one settled answer to difficult questions, but that there are various conversations going on, all of which engage with science in varying ways.

I give students a hand-out with quotations from authors representing the first five positions. I ask students to read the first quotation and provide a title for the position, or to give a 2-5 word summary of the author's approach. On the board, I gather student opinions, choose an appropriate title, and ensure that the basic idea of the position is clearly understood. Then I give the students 2-4 minutes to discuss in pairs the theological strengths, weaknesses, and scientific merits (when applicable) of the newly-entitled position. While they talk, I move from group to group gathering what is being said so that I can build a class recap from their discussions and logically order how I receive comments.

I cannot recap these discussions fully, but will outline each position below with suggestions or common positions taken by the students.

1) The sin approach

Quotation: "For it appears that all the evils of the present life, which experience proves to be innumerable, have proceeded from the same fountain. The inclemency of the air, frost, thunders, unseasonable rains, 
drought, hail, and whatever is disorderly in the world, are the fruits of sin." John Calvin ${ }^{3}$

Summary: When humans first sinned (with reference to Adam and Eve in the Garden of Eden - Genesis 2-3) the non-human world was corrupted, or cursed, resulting in all the natural causes for suffering and death. God never intended suffering to happen, it is a result of human $\sin$.

Strengths: It preserves God's goodness, and puts the entire blame for all suffering on human choice. Had those humans chosen differently, a world without suffering could have been a possibility.

Weaknesses: It seems highly unfair. Natural disasters kill indiscriminately and disproportionately to the sin of those affected. ${ }^{4}$ And it is highly unfair that humans born later should "inherit" the result of sins long preceding their own birth.

Scientific Merit: Very poor. First, behaviourally modern humans have only been around for 50,000 years, whilst earthquakes have been causing harm to life for all of the 3.8 billion years that life has existed. Calvin is not to blame for not incorporating these things: neither plate tectonics nor the old age of the earth were known in his time. But today, it is important to take the best science into account in theological work. The chronological problem here is insurmountable.

2) The Satanic influence approach

\footnotetext{
${ }^{3}$ John Calvin, Commentaries upon the First Book of Moses called Genesis (1554). In Calvin's Bible Commentaries: Genesis, Part I, translated by J. King (Forgotten Books, 1847/2007), 113.

${ }^{4}$ Newborn babies die, quite as often as adults, for example. The issue of disproportionate "punishment" was a particular issue in the devastating 1755 Lisbon earthquake, which has become classic case study in theodicy. Those in church on Saturday morning for the All Saints feast day had the great stone churches crumble on top of them. Worshippers who escaped the churches were threatened by fire, and ran to the harbor for shelter, at which point three tsunami waves crashed upon them. People visiting brothels on the edge of town on the feast day survived much better.
} 
Quotation: "To save theism from the charge of contradiction, all the theist has to do is to argue that natural evil is possibly due to the activity of Satan." William Abraham ${ }^{5}$

"It seems reasonable to suppose that the defection and rebellion in the angelic realm will drastically disorder the material world...Within this view, death, disease, division, and predation are seen as symptoms of this distortion, consequences of the angelic Fall rather than part of a the good order of creation." Michael Lloyd ${ }^{6}$

Summary: If suffering and natural disasters were around before evil humans could be the cause, a different agent could be the source instead. Some scholars point to Satanic evil, or the fall of the angels, as a reasonable agent to account for natural evil. ${ }^{7}$

Strength: It solves the chronological problem present in the first position and it protects God's blamelessness in relation to non-human animal pain and suffering.

Weaknesses: In the Old Testament, God regularly claims both that the world is good (Genesis 1) and that the uncontrollable elements of creation are particular points of pride (Psalm 104, Job 38-41). If they were the result of Satanic interference with an otherwise perfectly peaceful creation, it is a wonder that it is not stated more clearly. Scientific Merit: Problematic. Darwin's famous insight was that the diversity, beauty, and skill of the natural world is inseparably linked to the pain, suffering, and competition found in the natural world: "Thus, from the war of nature, from famine and death, the most exalted object

\footnotetext{
${ }^{5}$ Abraham, William J. An Introduction to the Philosophy of Religion (London: Prentice-Hall, 1985), 68.

6 "Are Animals Fallen?" in Animals on the Agenda, Linzey \&Yamamoto, eds. (London: SCM, 1998) 159.

${ }^{7}$ C. S. Lewis, author of The Chronicles of Narnia also said this: "It seems to me, therefore, a reasonable supposition, that some mighty created power had already been at work for ill on the material universe, or the solar system, or, at least, the planet Earth, before ever man came on the scene." The Problem of Pain (New York: HarperCollins, 1940/1996), 138.
} 
which we are capable of conceiving, namely, the production of the higher animals, directly follows." If Satan is the cause of Darwin's "war of nature", then Satan is also responsible for the developments of the beauty, skill and diversity produced by that conflict.

The conditions of life that humans and other animals need are created by the very same natural disasters that cause harm. Tectonic plate movement, for example, does cause earthquakes, but it also creates stable earth temperatures, the magnetic field that protects life from damaging solar rays, the renewal of nutrients in the soil, the existence of liquid surface water and many other benefits that make life possible. ${ }^{9}$ It would be odd if Satanic agents that intended to corrupt or destroy life by causing earthquakes actually gave the means of life's continuation.

3) The kenotic approach

Quotation: "God cannot unilaterally prevent genuine evil." "Because God's nature is first and foremost love, divine love is always and inherently uncontrolling. By 'uncontrolling,' I mean that God never controls creatures, situations, or worlds." Thomas Jay Oord ${ }^{10}$

Summary: The "kenotic" approach is drawn from the Greek word kenō in the passage Philippians 2:6-7 (NRSV), which says that Jesus, "who, though he was in the form of God, did not regard equality with God as something to be exploited, but emptied himself (ekenosen), taking the form of a slave, being born in human likeness." The basic approach is that although God has all power, God does not use power to control

\footnotetext{
${ }^{8}$ Charles Darwin, The Origin of Species (London: John Murray, 1859).

${ }^{9}$ See Peter Ward and Donald Brownlee. Rare Earth: Why Complex Life is Uncommon in the Universe (New York: Copernicus, 2004).

10 Thomas Jay Oord, The Uncontrolling Love of God (2015) 167; “Divine Action as Uncontrolling Love," available online at http://biologos.org/blogs/jim-stump-faith-and-science-seeking-understanding/divine-actionas-uncontrolling-love\#sthash.F8SoklGq.dpuf
} 
people or events, but takes the form of a servant and gives freedom to others.

By giving creation its "otherness," God also gives the world and all that is in it the ability to cause real harm. For Thomas Jay Oord, the nature of God's love is so completely uncontrolling that God cannot take away a creature's ability to do harm or experience harm without contradicting God's own love.

Strength: It explains why God does not prevent the harm caused by natural disasters or by other agents, such as predators. God, in creating, has given freedom to the world to be itself.

Weaknesses: A strong kenotic approach, as Oord takes, stands in contrast to the majority of the Christian tradition's understanding of God's sovereignty and power. While these kenotic views have proliferated since the profound human suffering witnessed during WWII, and is prominent in the writings of Jürgen Moltmann, Paul Fiddes, Clark Pinnock, Charles Hartshorne and many others, it does not explain why God cannot create new conditions (or perform miracles) to reduce or prevent harm.

Scientific Merit: This metaphysical position confirms the uniformity seen in the natural world. If God has given up the ability to control events, then we would expect material to move predictably, even if sometimes ruthlessly, according to natural laws.

4) Development (or "Nomic Regularity" or "Law-like regularity")

Quotation: "Why can't God suspend the regularities of nature whenever God had reason to do so? Consider a universe in which God could and did suspend at will the operation of (to begin with) physical regularities, a world (say) in which the murderer's bullet turned into a flower when it left his gun and floated gently to the ground... It is hard to see how the 
evolution of rational agency, not to speak of moral agency, would be possible in such a world." Philip Clayton and Steven Knapp ${ }^{11}$

Summary: Everyone relies on the regularity of the world in order to learn, to build skills, and to work out relationships with people and objects around them. If God interrupted that regularity to prevent people from being harmed, the end result would be a world where no relationships could have integrity and no skills could be built. I sometimes use the following examples with students: "Imagine a world where, when my brother and I fought as children, God always intervened to prevent harm. Every time I went to throw a punch, God created a feather pillow between my fist and my brother's arm. Or, every time he went to say something rude to me, God stopped the sound waves before they hit my ears. Would I have any real relationship with my brother? Similarly, if every time I slipped when running, God turned the road into marshmallow to soften my fall, would I ever really learn to run? I would begin to think that the miracle was the way the world really was."

Clayton and Knapp suggest that if God continually intervened, people and other living creatures could never build a true picture of the world, hold real relationships, or build the basic skills for life.

Strength: This approach is equally true for non-human animals. A mountain goat would never build its tremendous skill and strength if God prevented its being harmed by rocks and gravity.

Weaknesses: Taking this approach to an extreme prevents any allowance for miracles.

Scientific Merit: Again, this metaphysical position assumes the regularity of the world. It is also true that without an assumption of nomic regularity, no one could do science either.

11 Philip Clayton and Steven Knapp, The Predicament of Belief: Science, Philosophy, Faith (Oxford: Oxford University Press, 2011), 47. 
5) The physical package deal

Quotation: "Which would you rather have, a bursting planet or an earthquake here and there?" Father Joseph Lynch ${ }^{12}$

"The world is a package deal. We cannot experience the joys of existence without experiencing the aches of pain." Niels Gregersen ${ }^{13}$ Summary: There are no physical alternatives. The occasional earthquake is the price for a liveable earth surface. The suffering that people experience is due to the same complex neural system that also allows them feel profound joy and love. When worms, by contrast, are hit by natural disasters, they do not suffer. But worms cannot feel joy either. Strength: It is a strong argument: God is responsible for creating a world with conditions where life can, and often does, flourish. The only known conditions for life on our planet involve reliance upon earthquakes and other natural disasters that cause suffering.

Weaknesses: While science can show that life on this earth requires plate tectonics for life to flourish, it cannot prove that there are no other conditions under which life might develop and flourish.

Scientific Merit: This approach appropriates all that we know about the causes and effects of earthquakes and other natural disasters.

At this point, I take a break from looking at perspectives that try to explain why God allows natural disasters (or other natural harms) occur, and ask instead about how God might respond to the suffering of those caught up in these natural occurrences. Although I have included quotations below, I do not usually use them. I simply allow the students to mull over ideas in a brainstorming session and respond. Students usually come up with the idea that God might inspire people to give aid to those who are suffering, or to get

\footnotetext{
12 Father John Joseph Lynch, "In Defense of Earthquakes"

${ }^{13}$ Niels Gregersen, "The Cross of Christ in an Evolutionary World," Dialog 40:3 (Fall 2001): 192207, 201.
} 
involved in some other way. God might also be active in bringing healing to those who are physically or psychologically damaged. I then typically propose two last types of divine response to end the class.

6) The co-suffering approach

Quotation: "I can only suppose that God's suffering presence is just that, presence, of the most profoundly attentive and loving sort, a solidarity that at some deep level takes away the aloneness of the suffering creature's experience." Christopher Southgate ${ }^{14}$

Summary: Some theologians have proposed that, alongside other responses, God suffers with creatures in pain. God accompanies every creature through every pain.

Weaknesses: There is a long-standing debate in the Christian tradition that would argue that it is impossible for God to suffer. Suffering would mean the world affects God, whereas traditional views of God's impassibility hold that God is unchanging in perfection. Another critique is that it does not help if God does suffer. If my arm is broken, someone who set my arm in a cast, rather than someone who allowed their own arm to be broken too, would be a better help.

Strength: While this approach does not lessen the suffering of creatures, it does replace a certain view of God that I call the "Lord Farquaad God." In the movie Shrek, Lord Farquaad wants to rescue the Princess Fiona but is unwilling to go himself. Instead, he gathers a group of knights and commissions them with the task. In his speech, he includes the line "Some of you may die. But it's a sacrifice $I$ am willing to make." Divine co-suffering does not alleviate creaturely suffering, but it means that God does not nominate other creatures for suffering from which God is exempt.

\footnotetext{
${ }^{14}$ Christopher Southgate, The Groaning of Creation (Louisville, KY: Westminster John Knox, 2008), 53.
} 
7) Redemptive responses

Quotation: "Just as we hope that other human beings, given their propensities and needs, find appropriate fulfillment in life beyond death, we must hope that kindred creatures, given their propensities and needs, find fulfillment in life after death too... What a pelican chick might know as fulfillment of needs would have its own kind of harmony and intensity, one quite different from what we humans might know. If there is a pelican heaven, it is a pelican heaven." 15

Summary: Thinkers from across the theological spectrum are increasingly proposing that life after death is not just for humans. ${ }^{16}$ While some have held this view in the past (notably, John Wesley the founder of Methodism), it has never been a majority view. Now, it is becoming extremely prevalent. Heaven (or, better, the new creation) will incorporate the lives of non-human animals, particularly those who suffered, and allow them a chance to flourish.

Weaknesses: This can be evaluated as "too little, too late," or as improbable since a good and loving God was not able to give the suffering creatures a chance to flourish in this life. It raises the question, "Why didn't God just make heaven first?"

Strengths: The ability of God to creatively redeem suffering stands at the heart of the Christian faith. Christians believe that God took one of the cruellest occurrences in human history-the crucifixion of the blameless Jesus - and used it, with the resurrection, as the grounds for the salvation of the world. Because of this, millions now wear an instrument of death, the cross, as a sign of hope. For God to redeem the suffering of all sentient creatures would align well with the primary message of Christianity.

\footnotetext{
15 Jay McDaniel, Of God and Pelicans: A theology of reverence for life (Louisville, KY: Westminster John Knox, 1989), 45.

${ }^{16}$ See also work by David Clough, Christopher Southgate, Nicola Hoggard Creegan, Tom Wright, Elizabeth Johnson, Paul Griffiths, and Trent Dougherty.
} 
If there is any time left, I recap the major positions, and reemphasise that the goal is not to come to a certain conclusion or a single answer, but to explore how different perspectives highlight different questions about who God is, and how God might be present in circumstances of suffering. 